\title{
ANALISIS KESALAHAN PERCAKAPAN BAHASA INDONESIA SISWA ASING DALAM TAYANGAN KELAS INTERNASIONAL STASIUN TELEVISI NET
}

\author{
Mumun Siti Munawwaroh \\ Universitas Negeri Jakarta \\ mumunmunawwaroh@gmail.com
}

\begin{abstract}
ABSTRAK
Penelitian ini bertujuan untuk mengetahui kesalahan strategi permukaan dalam percakapan bahasa Indonesia yang dilakukan oleh siswa asing dalam tayangan Kelas Internasional. Tayangan Kelas Internasional merupakan suatu acara televisi mengenai pembelajaran bahasa Indonesia bagi pelajar asing (BIPA). Di dalamnya terdapat percakapan bahasa Indonesia siswa asing yang belajar bahasa Indonesia. percakapan bahasa Indonesia itu terjadi baik saat pembelajaran maupun di luar pembelajaran, baik terjadi antarsiswa atau antarsiswa dengan guru dan staf sekolah. Penelitian ini menggunakan metode deskriptif kualitatif dengan analisis isi. Data berupa percapakan bahasa Indonesia siswa dianalisis untuk ditemukan kesalahannya. Pembelajaran BIPA Kelas Internasional diikuti oleh Lingling asal Republik Rakyat China (RRC), Kotaro asal Jepang, Lee Jong Yu asal Korea Selatan, Tyson asal Australia, Carlos asal Kolumbia, Angelina asal Brazil, Abbas asal Nigeria dan Mrs. Palak asal India. Kesalahan yang dilakukan terbagi menjadi empat macam yaitu kesalahan omission, addition, misformation, dan misorder. Dalam 20 episode yang dianalisis, terjadi kesalahan omission sebanyak 2 kali, kesalahan addition sebanyak 36 kali, kesalahan misformation sebanyak 14 kali, dan kesalahan misorder sebanyak 8 kali. Hasil dari penelitian ini dapat digunakan sebagai salah satu contoh kasus pembelajaran BIPA di Indonesia atau di luar negeri.
\end{abstract}

Kata kunci: analisis kesalahan, BIPA, percakapan, bahasa Indonesia, strategi permukaan

\section{A. PENDAHULUAN}

Bahasa Indonesia sebagai bahasa nasional negara Indonesia juga dikena loleh Negara lain sebagai bahasa asing. Menurut Wurianto (2015),sebagai bahasa asing bahasa Indonesia tersebar luas untuk dipelajari di 46 negara-negara di Asia, Australia, Amerika, Afrika, Eropa, danTimur Tengah. Selain itu bahasa Indonesia juga disejajarkan dengan empat bahasa asing yaitu bahasa Cina, bahasa Perancis, bahasa Jepang dan bahasa Belanda. Hal tersebut menunjukkan bahwa banyak
Negara berminat untuk mempelajari bahasa Indonesia.

Dalam hal ini di Indonesia terdapat lembaga untuk melaksanakan pembelajaran tersebut, baik itu lembaga yang berasal dari pemerintah ataupun lembaga yang berasal dari perguruan tinggi tertentu atau dari perseorangan. Lembaga tersebut dinamakan dengan bahasa Indonesia bagi pelajar asing (BIPA).

Badan Bahasa mencatat bahwa terdapat banyak lembaga BIPA di dalam maupun di luar negeri. Di dalam negeri 


\section{DEIKSIS - JURNAL PENDIDIKAN BAHASA DAN SASTRA INDONESIA}

tercatat tidak kurang dari 45 lembaga yang mengajarkan BIPA. Jumlah lembaga tersebut terbagi menjadi dua jenis, yaitu lembaga BIPA di perguruan tinggi dan lembaga BIPA luar perguruan tinggi atau lembaga kursus. Sementara itu, jumlah lembaga BIPA di luar negeri tidak kurang dari 130 lembaga yang terdiri dari perguruan tinggi, pusat-pusat kebudayaan asing, KBRI, dan lembaga-lembaga kursus.

Selain lembaga bahasa yang tersebut di atas, terdapat satu acara televisi yang menyajikan pembelajaran BIPA. Acara tersebut ditayangkan mulai dari tahun 2015 dengan nama Kelas Internasional. Kelas Internasional ditayangkan setiap hari Senin hingga Jumat pada pukul 18.30 selama 30 menit. Di dalam tayangan Kelas Internasional terdapat sekolah bahasa yang mengajarkan BIPA. Bahasa Indonesia selalu digunakan oleh staf sekolah untuk berinteraksi dengan siswa, baik di dalam pembelajaran maupun di luar pembelajaran. Jumlah siswa sebanyak 8 siswa dan berasal dari berbagai negara. Siswa-siswa tersebut adalah Lingling asal Republik Rakyat China (RRC), Kotaro asal Jepang, Lee Jong Yu asal Korea Selatan, Tyson asal Australia, Carlos asal Kolumbia, Angelina asal Brazil, Abbas asal Nigeria, dan Mrs. Palak asal India.

Siswa-siswa tersebut belajar bahasa Indonesia dengan tujuan masing-masing. Misalnya Lingling belajar bahasa Indonesia karena sudah tinggal di Indonesia dan bekerja di Bank of China yang ada di Indonesia. Hal tersebut menggambarkan bahwa pembelajaran bahasa Indonesia bagi penutur asing mencakup pembelajaran bahasa secara praktis. Bahasa Indonesia diajarkan tidak secara teoretis, tetapi diajarkan melalui interaksi-interaksi penutur sesuai dengan jenis kebutuhan dan kondisi yang terjadi. Hal ini menurut Wojowasito (1977) dimaksudkan agar penutur asing lebih mudah mempelajari bahasa Indonesia secara langsung dalam kehidupan sehariharinya. Hal ini dimaksudkan bahwa penutur asing diharapkan mampu mempergunakan bahasa Indonesia untuk berbicara lancar dan sekaligus dapat mengerti bahasa yang diujarkan penutur aslinya.

\section{B. KAJIAN TEORETIS \\ a. Analisis Kesalahan}

Berdasarkan Dulay, Burt dan Krashen (1982) kesalahan merupakan sebuah sisi ke cacatan siswa di dalam berbicara ataum enulis. Hal itu merupakan bagian dari percakapan atau komposisi suatu bahasa yang benar. Hal tersebut menunjukkan bahwa percakapan dapat digunakan menjadi sumber utama dalam analisis kesalahan. Dalam hal kesalahan siswa, Corder (1982) menjelaskan bahwa kesalahan-kesalahan yang terjadi di dalam pembelajaran bahasa kedua adalah berasal dari kebiasaan bahasa pertama. Maka, pembelajaran bahasa kedua memungkinkan siswa melakukan kesalahan.

Analisis kesalahan atau Error Analysis (EA) menurut Ellis dan Barkhuizen (2005) juga merupakan satu keutuhan prosedur yang dimulai dari mengidentifikasi, menggambarkan, dan menjelaskan kesalahan siswa. Selain itu juga evaluasi kesalahan atau Error Evaluation (EE) merupakan bagian dari prosedur tersebut yang dilakukan 


\section{DEIKSIS - JURNAL PENDIDIKAN BAHASA DAN SASTRA INDONESIA}

untuk menilai atau mengevaluasi kesalahan yang dilakukan oleh siswa.

Pada saat pembelajaran bahasa kedua, siswa mempelajari bahasa baru yang berbeda dari bahasa pertamanya sehingga melakukan kesalahan berbahasa. Kesalahan berbahasa yang dilakukan siswa dapat dilihat dan dianalisis oleh pengajar. Suatu analisis kesalahan berawal dari teori pembelajaran bahasa keduanya itu analisis kontrastif yang mencoba melihat transfer bahasa kedua dan atau bahasa target sebagai proses utama. Hal tersebut berbeda dengan analisis kesalahan. Fokus analisis kesalahan adalah melihat dan memperhitungkan kinerja siswa secara kognitif dalam proses pembelajaran bahasa kedua atau bahasa target, yaitu dengan melihat kesalahan berdasarkan bukti kesalahan siswa dan memberikan pemahaman terhadap siswa dalam pembelajaran bahasa kedua atau bahasa target tersebut (Keshavarz, 2012).

\section{b. Kesalahan Strategi Permukaan}

Teori taksonomi kesalahan menurut Dulay, Burt dan Krashen (1982) terbagi menjadi empat kategori yaitu, kategorilinguistik; (2) strategi permukaan; (3) analisis komparatif; dan (4) efek komunikatif. Di dalam kategori linguistik, analisis kesalahan dilakukan pada tataran fonologi, sintaksis dan morfologi (tata bahasa), semantic dan leksikon, serta wacana. Selain kesalahan linguistik, salah satu sorotan untuk melakukanan alisis kesalahan adalah dengan melihat kesalahan permukaan struktur. Kesalahan ini terjadi di luar kesalahan linguistic sehingga dinamakan dengan analisis kesalahan permukaan atau strategi permukaan.

Strategi permukaan menyoroti cara permukaan struktur yang diubah. Siswa dapat menghilangkan yang perlu (omit), menambahkan ( $a d d)$ yang tidak perlu, siswa juga melakukan kesalahan bentuk (misform) atau kesalahan urutan (misorder).

Pertama yaitu omission. Kesalahan ini ditandai dengan tidak adanya salahsatu yang seharusnya ada di dalam percakapan. Misalnya morfem yang membawa makna referensial suatu kalimat, dapat berupa nomina, verba, ajektifa, dan adverbia.

Kedua yaitu addition. Terdapat kesalahan tersebut jika munculnya sesuatu yang tidak seharusnya di dalam komposisi percakapan. Terdapat tiga tipe kesalahan dalam penambahan (addition), yaitu double markings, regularization dan simple addition. Double markings adalah dengan menambahkan penjelasan yang salah sehingga menjadikan bentuk linguistic itu salah. Yang kedua regularization merupakan kesalahan dalam menggeneralisasikan aturan reguler (umum) kepada pembentukan katakata tertentu yang tidak reguler (tidak umum). Misalnya kata eated, seharusnya ate. Yang terakhir, simple addition yaituj enis kesalahan penambahan yang tidak termasuk ke dalam double markings atau regularization.

Ketiga yaitu misformation. Kesalahan ini ditandai dengan penggunaan bentuk yang salah dari morfem atau tata bahasa. Di dalam kesalahan misformation terdapat tiga jenis kesalahan, yaitu berikut ini.

1. Regularization errors, kesalahan yang menggenaralisasikan struktur yang 
seharusnya berbeda dari struktur general atau regular.

2. Archi-forms, kesalahan yang kaitannya terhadap pemerolehan bahasa kedua yaitu kesalahan dalam mepresentasikan bentukbentuk linguistik. Misalnya bentuk ajektiva, jamak atau lainnya.

3. Alternating forms, bentuk yang terbalik atau kesalahan ini dapat dikatakan sebagai kesalahan dalam menempatkan bentuk yang bukan pada pasangannya. Misalnya pada struktur jamak, ajektiva maskulin dan feminine atau lainnya.

Terakhir yaitu misordering. Misordering adalah kesalahan penempatan morfem atau sekumpulan morfem di dalam percakapan. Atau dengan kata lain misordering ini mengakibatkan posisi yang tertukar dari seharusnya.

\section{METODOLOGI}

Penelitian ini menggunakan tayangan yang diunduh melalui youtube sebanyak 20 episode. Metode penelitian ini yaitukualitatif deskriptif dengan menggunakan analisis isi. Prosedur dalam penelitian ini yaitusebagai berikut, 1) mengumpulkan data percakapan bahasa Indonesia siswa; 2) daftar setiap percakapan antarsiswa dan siswa dengan guru serta identifikasikan; 3) jelaskan kesalahan berbahasa dan taksonomi kesalahan yang terjadi pada bahasa target; 4) tentukan jenis kesalahan berbahasa dan taksonomi berbahasa siswa.

\section{PEMBAHASAN}

Percakapan bahasa Indonesia yang dilakukan olehsiswa asing dalam tayangan Kelas Internasional terjadi, baik saat pembelajaran maupun di luar pembelajaran. Dalam interaksi antarsiswa ataupun siswa dengan guru maupun staf sekolah menimbulkan kesalahan strategi permukaan. Kesalahan strategi permukaan terbagi menjadi empat macam, yaitu kesalahan omission, addition, misformation, dan misordering. Berikut ini tabel yang berisi beberapa contoh kesalahan strategi permukaan yang dilakukan oleh siswa dalam tayangan Kelas Internasional.

Tabel 1. Kesalahan Strategi Permukaan

\begin{tabular}{|c|c|c|c|}
\hline No. & Percakapan & Koreksi & $\begin{array}{c}\text { Jenis } \\
\text { Kesalahan }\end{array}$ \\
\hline 1. & $\begin{array}{l}\text { Abbas: } \\
\text { "Apa? Murid } \\
\text { bau?" } \\
\text { Lingling: } \\
\text { "Bukan mulid } \\
\text { bau. Mulid } \\
\text { balu." }\end{array}$ & $\begin{array}{l}\text { Abbas: } \\
\text { "Apa? Murid } \\
\text { baru?" }\end{array}$ & omission \\
\hline 2. & $\begin{array}{l}\text { Pak Budi: } \\
\text { Selanjutnya } \\
\text { saya minta, } \\
\text { kamu. Silakan } \\
\text { perkenalkan } \\
\text { diri kamu. } \\
\text { Nama, asal } \\
\text { negara dan } \\
\text { pekerjaan. } \\
\text { Leee Jong Yu: } \\
\text { Ne, annyong } \\
\text { haseyo. } \\
\text { Pak Budi: } \\
\text { Maaf, bahasa } \\
\text { Indonesia. } \\
\text { Lee Jong Yu: } \\
\text { Ba ha sa Indo }\end{array}$ & $\begin{array}{l}\text { Lee Jong Yu: } \\
\text { Ba ha sa Indo } \\
\text { ne sia. } \\
\text { Nama saya Lee } \\
\text { Jong Yu. Saya } \\
\text { dari Korea } \\
\text { Selatan. E saya } \\
\text { suka menyanyi } \\
\text { (diperagakan). } \\
\text { Menyinya }\end{array}$ & misformation \\
\hline
\end{tabular}




\section{DEIKSIS - JURNAL PENDIDIKAN BAHASA DAN SASTRA INDONESIA}

\begin{tabular}{|c|c|c|c|}
\hline & $\begin{array}{l}\text { ne sia. } \\
\text { Nama saya Lee } \\
\text { Jong Yu. Saya } \\
\text { dari Korea } \\
\text { Selatan. E saya } \\
\text { suka menyinya } \\
\text { (diperagakan). } \\
\text { Menyinya }\end{array}$ & & \\
\hline 3. & $\begin{array}{l}\text { Pak Budi: } \\
\text { Tujuan saya } \\
\text { menyuruh } \\
\text { kalian } \\
\text { membawa } \\
\text { barang-barang } \\
\text { khas Indonesia } \\
\text { adalah untuk } \\
\text { menguji } \\
\text { seberapa besar } \\
\text { kalian } \\
\text { mengenal } \\
\text { Indonesia. } \\
\text { Tyson, bawa } \\
\text { barangnya ke } \\
\text { depan. Lalu } \\
\text { ceritakan } \\
\text { barang yang } \\
\text { kamu bawa. } \\
\text { Tyson: } \\
\text { Ini wayang } \\
\text { golek } \\
\text { namanyaCopet. }\end{array}$ & $\begin{array}{l}\text { Tyson: } \\
\text { Wayang golek } \\
\text { ini } \\
\text { namanyaCepot. } \\
\text { Tyson: } \\
\text { Wayang golek } \\
\text { ini namanya } \\
\text { Cepot. }\end{array}$ & $\begin{array}{l}\text { misordering } \\
\text { misformation }\end{array}$ \\
\hline 4. & $\begin{array}{l}\text { Pak Budi: } \\
\text { Ini kejutan. } \\
\text { Saya tidak } \\
\text { pernah mengira } \\
\text { kalau kotaro } \\
\text { memilih } \\
\text { barang khas } \\
\text { Indonesia yaitu } \\
\text { gendang. } \\
\text { Silakan kamu } \\
\text { ceritakan } \\
\text { tentang } \\
\text { gendang. } \\
\text { Kotaro: } \\
\text { Ini gendang. E } \\
\text { untuk } \\
\text { mengiringgi } \\
\text { tari-tarian khas } \\
\text { Indonesia. }\end{array}$ & $\begin{array}{l}\text { Kotaro: } \\
\text { Ini gendang. E } \\
\text { untuk } \\
\text { mengiringi } \\
\text { tari-tarian khas } \\
\text { Indonesia. }\end{array}$ & addition \\
\hline
\end{tabular}

\begin{tabular}{|l|l|l|l|}
\hline & $\begin{array}{l}\text { Sueb: } \\
\text { Just minute } \\
\text { okay? } \\
\text { Warm warm. } \\
\text { Ah cacing. }\end{array}$ & \\
5. & $\begin{array}{l} \\
\text { Inu Kantin: } \\
\text { cacing? }\end{array}$ & $\begin{array}{l}\text { Carlos: } \\
\text { Bukan. Warm } \\
\text { itu hangat. }\end{array}$ & addition \\
Sueb: & $\begin{array}{l}\text { Iya. } \\
\text { Carlos: } \\
\text { Bukan. Warm } \\
\text { itu hanggat. }\end{array}$ & \\
\hline
\end{tabular}

Percakapan antara Abbas dan Lingling di atas menunjukkan bahwa Abbas melakukan kesalahan omission.Pengucapan kalimat Murid bau? merupakan kesalahan pengurangan atau omission. Kalimat Murid bau? dikoreksi menjadi Murid baru? oleh Lingling dengan benar.

Selanjutnya yaitukesalahan dengan menambahkan yang tidak seharusnya, addition. Kesalahan ini menempati kesalahan terbanyak dalam percakapan yang dilakukan oleh kedelapan siswa asing dalam Kelas Internasional. Dalam percakapan antara Pak Budi dan Kotaro terlihat bahwa Kotaro melakukan kesalahan addition yaitu Kotaro menyebutkan kata <mengiringgi> yang seharusnya mengucapkan kata $<$ mengiringi>.

Selain dua kesalahan di atas, terdapat dua kesalahan lainnya yang berhubungan dengan letak, yaitu misformation dan misordering. Kesalahan misformation terjadi pada Lee Jong Yu. Lee mengucapkan <menyanyi> menjadi <menyinya>. Sementara itu, kesalahan misordering 


\section{DEIKSIS - JURNAL PENDIDIKAN BAHASA DAN SASTRA INDONESIA}

dilakukan oleh Tyson saat mengucapkan kalimat Ini wayang golek namanya Cepot. Kalimat tersebut dikoreksi menjadi Wayang golek ini namanya Cepot.

\section{E. SIMPULAN}

Hasil penelitian ini menunjukkan kesalahan strategi permukaan dilakukan oleh siswa asing di dalam tayangan Kelas Internasional sebanyak 60 buah kesalahan. Kesalahan-kesalahan tersebut terbagi menjadi kesalahan berupa omission sebanyak 2 buah, kesalahan addition berjumlah 36 buah, kesalahan misformation sebanyak 14 buah dan kesalahan misordering sebanyak 8 buah.

Kesalahan strategi permukaan dilakukan oleh seluruh siswa dalam Kelas Internasional kecuali Mrs. Palak yang memang selama belajar dia belum menggunakan bahasa Indonesia secara aktif. Tayangan Kelas Internasional ini merupakan tayangan pertama di Indonesia dalam memperlihatkan pembelajaran BIPA. Oleh karena itu, hasil dari penelitian ini dapat digunakan sebagai salah satu contoh kasus pembelajaran BIPA oleh pengajar BIPA. Selain itu dapat juga digunakan sebagai salah satu model pembelajaran BIPA di kelas BIPA sebenarnya.

\section{F. DAFTAR PUSTAKA}

Badan Bahasa Kemendikbud. (2018). Profil Bipa Badan Pengembangan dan Pembinaan Bahasa (online)http://badanbahasa.kemdikbu d.go.id/lamanbahasa/info_bipa, diakses 28 Juli 2018.
Corder, S.P. (1982).Error Analysis and Interlanguage. Oxford: Oxford University Press.

Dulay, Heidi C. (1982). Language Two. New York: Oxford University Press.

Keshavarz, Mohammad Hossein. (2012). Contrastive Analysis and Error Analysis. Tehran: Rahnama Press.

Rod Ellis, Gary Barkhuizen, Analysing Learner Language, (Oxford: Oxford University Press: 2005), h. 51.

Wojowasito, S.

(1977).PengajaranBahasaKedua

(BahasaAsing, BukanBahasalbu). Bandung: Shinta Dharma.

Wurianto, Arif Budi. (2015). Cultural Approach in Teaching Indonesian Language for Foreigners, Proceedings of the $5^{\text {th }}$ Malaysia International Conference on Foreign Language (MICFL 2015), 121. 